\title{
A systematic proximity map of the centriole-cilia interface
}

\author{
J Gonçalves, B Mojarad, G Gupta, E Coyaud, B Raught, L Pelletier* \\ From Cilia 2014 - Second International Conference \\ Paris, France. 18-21 November 2014
}

\section{Objective}

Eukaryotic cilia/flagella are dynamic microtubule (MT)based organelles. The ciliary axoneme is built from a radial scaffold of 9 MT doublets, plus a central MT pair, in the case of motile cilia. The axoneme is templated by a basal body (BB)/centriole derived from the mother centriole, in the case of animal cells, which presents sub-distal and distal appendages critical for cilia formation. In vertebrates, different cilia types fulfil diverse functions, critical for embryonic development and homeostasis of adult tissues. Cilia malfunction causes ciliopathies, but despite their biomedical implications, their molecular composition and mechanisms underlying their biogenesis still remain poorly defined.

\section{Methods}

In order to dissect the mechanisms involved in primary cilia assembly and disassembly we decided to focus on the mother centriole appendages and the $\mathrm{TZ}$ and define the interaction networks of their known components ( 60 proteins) using a new mass spectrometry approach called BioID based on the proximity-dependent biotinylation of proteins by a promiscuous biotin ligase fused to the protein of interest.

\section{Results}

With this approach we have identified near neighbors and potential new interactors of $\sim 60$ known components of the centriole-cilia interface and the ciliary transition zone which have been tested for their involvement in centrosome and cilia biology using automated highthroughput/high-resolution screens and precise morphometric measurements.

\footnotetext{
$\overline{L A B}$, Lunenfeld-Tanenbaum Research Institute, Mount Sinai Hospital, Toronto,
} Ontario, Canada

(c) 2015 Gonçalves et al. This is an Open Access article distributed under the terms of the Creative Commons Attribution License (http://creativecommons.org/licenses/by/4.0), which permits unrestricted use, distribution, and reproduction in any medium, provided the original work is properly cited. The Creative Commons Public Domain Dedication waiver (http://creativecommons.org/ publicdomain/zero/1.0/) applies to the data made available in this article, unless otherwise stated. and take full advantage of:

- Convenient online submission

- No space constraints or color figure charges

- Immediate publication on acceptance

- Inclusion in PubMed, CAS, Scopus and Google Scholar

- Research which is freely available for redistribution Submit your manuscript at
www.biomedcentral.com/submit C BioMed Central
- Thorough peer review 